\title{
TV/Series
}

$6 \mid 2014$

Écho et reprise dans les séries télévisées (III) : de la métafiction à la transmédialité

\section{High Fidelity: Adapting Fantasy to the Small Screen}

\section{Shannon Wells-Lassagne}

\section{(Q) OpenEdition}

\section{Journals}

Electronic version

URL: http://journals.openedition.org/tvseries/343

DOI: $10.4000 /$ tvseries.343

ISSN: 2266-0909

Publisher

GRIC - Groupe de recherche Identités et Cultures

Electronic reference

Shannon Wells-Lassagne, « High Fidelity: Adapting Fantasy to the Small Screen », TV/Series [Online],

6 | 2014, Online since 01 December 2014, connection on 21 April 2019. URL : http://

journals.openedition.org/tvseries/343; DOI : 10.4000/tvseries.343

\section{(c) (i) (9)}

TV/Series est mis à disposition selon les termes de la licence Creative Commons Attribution - Pas d'Utilisation Commerciale - Pas de Modification 4.0 International. 


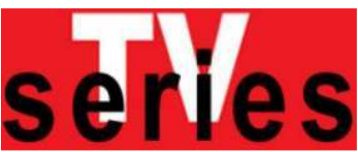

High Fidelity: Adapting Fantasy to the Small Screen Shannon WELLS-LASSAGNE

In an article in The Atlantic, Alyssa Rosenberg compares HBO series Game of Thrones to True Blood in an attempt to pinpoint the ways in which the first succeeds where the older series fails. In the end, the author determines that it all comes down to fidelity: Alan Ball's show has added to the cast and the themes without building a convincing world for them to people, while Game of Thrones has remained true to the George R.R. Martin novel from which it draws its name, streamlining and adding to the characterization, rather than the character list.

Of course the fact that fidelity is the core issue argued here is ironic for several reasons: not only is it at odds with everything that adaptation theory has argued for decades, but historically filmmakers originally turned to less "high literature" source texts in order to avoid the necessity to be faithful to a text made sacred by the canon, thus spawning some of the more successful if less faithful noir films. Beyond this, Ball himself has argued against fidelity, insisting that as the novel is in the first person, he has to tell everyone's story, and that he wants readers of the original Charlaine Harris novels to be surprised. As such, I would like to examine the way that each approaches this specific issue of echoes of the source text in the finished product. Ultimately, I will argue that True Blood seeks to increase the echo, by creating a constant distance not only from its source text but also from its characters and the events its recounts. After all, True Blood recounts a world much like our own, that just so happens to be populated by supernatural creatures - by creating various defamiliarizing elements (including invented episodes, but also comic or outrageous effects to distance the viewer from the characters' emotions), the show creators force us to pull back from the story and consider its implications. Game of Thrones, on the contrary, wants to pull the reader in, minimizing this "echo": when creating a world more typical of the fantasy genre, with religions, languages, and political hierarchies that are familiar to the characters but not the viewer, a distancing effect would be disastrous to the suspension of disbelief necessary to enter these new worlds.

I will also argue that the "source text" is not singular in either case - the two series adapt not just a novel or series of novels, but a tradition. True Blood cannot be studied separately from the long tradition of vampire texts equating vampirism with sexuality, and certainly is set up in echo (and contrast) to the more recent phenomenon of teenage vampire romances, where the "messy" aspects of sex (and its inevitable moral and politica ramifications) become manifest in the death and gore characteristic of the series. Likewise, Game of Thrones clearly harkens back to that founding text of the fantasy genre, The Lord of the Rings (as well as its film adaptation), and replaces Tolkien's nostalgia with a voluntarily "gritty" realism, where rape, murder, corruption and general injustice makes it an echo of our own imperfect society. As such, we can argue that though the two series take very different approaches to the idea of fidelity, their end goal seems to be similar: they seek to heighten the viewer's awareness of the political ramifications of these fantasy worlds, and so acknowledge the echoes to be found in the world outside the television screen.

hen considering issues like echoes and refrains in relation to television, the theme of adaptation seems an obvious one: adaptations necessarily imply a distance (in format, if not in content) between source text and television adaptation, and the resulting reverberations make for a profitable analysis of the specificities of television and text. In recent years, there have been two notable fantasy adaptations to grace our screens: Game of Thrones (HBO, 2011- ) and True Blood (HBO, 2008- ). Adaptations are nothing new to the small screen - like feature-length films, adaptations have 
long been a mainstay of commercial television, but for the most part, they have been what British and American people refer to as miniseries, short-lived series of adaptations of generally classic novels that are not destined to see another season, like the many BBC adaptations of classic $19^{\text {th }}$-century novels (Austen, Dickens...) or American miniseries like Roots (ABC, 1997) or Lonesome Dove (CBS, 1989) - or, less prestigiously, countless Danielle Steele novels. The recurring television adaptations tend to fall into the category of genre fiction, as with Agatha Christie's Poirot novels (or in France, Simenon's Maigret) and this is no doubt to be expected - genre fiction privileges the sequels and long-running series more adapted to TV format with its voracious need for a large number of stories. In genre fiction, most of these are detective stories or procedurals - genres that are not only already well-established on the small screen, but also less expensive and less risky than the other very popular type of genre fiction, fantasy. Fantasy after all necessarily requires special effects, with budgets that may not be within reach for television shows, and fantasy has - until now - remained more of a niche market, with a die-hard audience, but which did not necessarily translate into a popular following in the general public.

Things have changed, however - in the wake of Buffy the Vampire Slayer (The WB, 1997-2001, UPN, 2011-03), X-Files (FOX, 1993-2002), Xena: Warrior Princess (Syndication, 1995-2001) Lost (ABC, 2004-10), or Supernatural (The WB, 2005-2006, The CW, 2006- ) - the fantastic has made its successful appearance on the small screen $^{1}$, no doubt explaining HBO's willingness to translate the works of Charlaine Harris and George R.R. Martin to the screen. The supernatural series I have just mentioned, however, are all original series without a source text (unless you count the feature-length film version of Buffy, which creator Joss Whedon has essentially disowned as having little to nothing to do with his original idea and/or screenplay $^{2}$ ). Having fantasy adaptations is new, and though Vampire Diaries (The CW, 2009-) has since followed in the wake of True Blood (partially in response to the popularity of True Blood and the Twilight franchise), Alan Ball brought this innovation to the screen after his previous success with Six Feet Under (HBO, 2001-05) or American Beauty (1999).

${ }^{1}$ The supernatural was fairly popular in the 1960 s and 70s, with supernatural sitcoms like Bewitched (ABC, 1964-72), The Munsters (CBS,1964-66), or The Addams Family (ABC, 1964-66), or action shows like The Incredible Hulk (CBS, 1978-82) or Wonder Woman (ABC, 1975-79), but had since died out, and had never really been treated in the guise of drama.

${ }^{2}$ With the notable exception of the comic-book adaptations The Incredible Hulk and Wonder Woman, as mentioned above; one may of course question whether or not superhero fiction constitutes fantasy or not, though a complete definition is beyond the boundaries of this analysis. 
The fact that these are adaptations rather than original series may seem relatively unimportant when talking about television series; indeed, given the number of predecessors, one could perhaps call into question the extent to which these series are novel at all. But their role as adaptation is in fact crucial. After all, these series were largely chosen because of a significant fan base of faithful readers, implying a built-in audience, as well as an impressive pool of stories from which to draw for inspiration3: these are sound reasons to take on sagas that otherwise imply intimidatingly large budgets in order to convince its audience. Indeed, Game of Thrones cost approximately 60 million dollars for Season 1, and the budget increased by $15 \%$ for Season 2, each of which was only 10 episodes to the traditional 12 for HBO series $^{4}$.

To a large extent this paper was inspired by an article in The Atlantic, where writer Alyssa Rosenberg compares The Game of Thrones to True Blood in an attempt to pinpoint the ways in which the first succeeds where the older series fails ${ }^{5}$. In the end, the author determines that it all comes down to fidelity: Alan Ball's show has added to the cast and the themes without building a convincing world for them to people, while Game of Thrones has remained true to the George R.R. Martin novel from which it draws its name, streamlining and adding to the characterization, rather than the character list.

Of course the fact that fidelity is the core issue argued here to explain the success or failure of a series is ironic for several reasons: not only is it at odds with everything that adaptation theory has argued for decades 6 , but historically filmmakers originally turned to less "high literature" source texts in order to avoid the necessity to be faithful to a text made sacred by the canon, thus spawning some of the more

3 The Southern Vampire Mysteries upon which True Blood is based had just published its $12^{\text {th }}$ installment of Sookie Stackhouse adventures (Deadlocked, published in May 2012), and $A$ Song of Ice and Fire, the source text for Game of Thrones, has five volumes, doorstoppers of about 800 pages each, the last of them (A Dance with Dragons) clocking in at 1100 pages.

4 June Thomas, "How much gold is Game of Thrones worth?", Slate, March $29^{\text {th }}, 2012$ http://www.slate.com/articles/arts/culturebox/2012/03/game of thrones how hbo an d showtime make money despite low ratings .html, last consulted December $8^{\text {th }}, 2014$ 5 Alyssa Rosenberg, "Fantasy on TV: How 'Game of Thrones' succeeds where 'True Blood' fails", The Atlantic, August 31, 2011.

http://www.theatlantic.com/entertainment/archive/2011/o8/fantasy-on-tv-how-game-ofthrones- succeeds-where-true-blood-fails/244365/, last consulted December $8^{\text {th }} 2014$.

${ }^{6}$ Current adaptation theory has essentially been constructed on a refusal of the premise that adaptations can only be analysed in relation to their faithfulness to their sources; $\mathrm{cf}$ Kamilla Elliott, Rethinking the Novel/Film Debate, Cambridge, Cambridge University Press, 2003; Linda Hutcheon, A Theory of Adaptation, New York, Routledge, 2006; Thomas Leitch, Film Adaptation and Its Discontents: From Gone with the Wind to The Passion of the Christ, Baltimore, John Hopkins University Press, 2007; Robert Stam (ed.), Literature and Film: A Guide to the Theory and Practice of Film Adaptation, Malden, MA, Blackwell, 2005; Deborah Cartmell and Imelda Whelehan, Screen Adaptation: Impure Cinema, London, Palgrave Macmillan, 2010. 
successful if less faithful noir films. Beyond this, Alan Ball himself has argued against fidelity, insisting on its unfeasibility since the novel is in the first person, and he has to tell everyone's story, and adding that he wants readers of the original Charlaine Harris novels to be surprised 7 . As such, I would like to examine the way that each approaches this specific issue of echoes of the source text in the finished product. Are these series "faithful"? To what? To whom? Fidelity, I would like to suggest, is not so simple as the relationship between text and television: the two series contain echoes not only of the source texts, but of their genre, their medium, their audience, and above all, their respective creators' vision. As such, though I'll mention the relationship between text and series briefly, I'll be focusing on those other influences - the hidden source texts that the series are also adapting.

My initial comment that the obsession with fidelity is ironic is somewhat disingenuous: after all, though hard boiled novels allowed for new innovation both in terms of themes and aesthetics in film, conversely popular literature often has harsher standards for fidelity than does classic literature: thus the rumor about David Selznick not worrying about fidelity to Jane Eyre, but being frantic about retaining the essence of Daphne Du Maurier's Rebecca or Margaret Mitchell's Gone with the Wind, because "people have actually read them"8. It is clear that more people were attentive to the fidelity of the Harry Potter adaptations than they were to the adaptations of Vanity Fair, for example, and cult series like A Song of Ice and Fire or the Southern Vampire Mysteries could definitely expect to garner the same type of critical attention. Rosenberg's criticisms, then, are unsurprising, but they are important in that the ultimate success of the series is linked to their success at translating as much of the source text as possible to the screen. Anyone who has seen faithful but lifeless adaptations of classic texts knows that this is not the case, and as such, we must ask ourselves if this is a case of the writer being overwhelmed with a case of "the book-was-better-itis" common in fans or if there are specific problems in adapting fantasy that should be addressed.

Upon first glance, it seems clear that Game of Thrones plays the fidelity game much more than does True Blood: author George R.R. Martin is an executive producer for the series and writes at least one episode per season, and the series goes to great pains to reproduce the feel of the world of Westeros in which the series takes place, even going so far as to mimic the structure of the novels themselves (each chapter

7 Tim Stack, “True Blood': Alan Ball and Charlaine Harris discuss Sunday's shocking death of [SPOILER]", Entertainment Weekly, July $12^{\text {th }}, 2011$.

www.insidetv.ew.com/2011/07/12/true-blood-alan-ball-claudine-death/, last consulted December 2014.

8 James Naremore, "Introduction", Film Adaptation, New Brunswick, NJ, Rutgers University Press, 2000, p. 11-12. 
is told from a different character's point of view, set in a different place and focusing on a different plot than the one before; the series makes very effective use of cross cutting to similar effect). Alan Ball, on the other hand, seems resolutely opposed to fidelity to his source texts - in the fifth season, the series barely touched on the primary plot of the corresponding novel, Dead as a Doornail, where shapeshifters, having recently gone public like the vampires at the beginning of the series, are now subject to attack. This idea was minimized (shifters are still secret, and the recently retired local sheriff and square dancing champion is the "evil genius" behind the plot - his own ludicrous status tells the viewer much about the import of the plotline as a whole), while original storylines and characters largely dominated the season. Though season 1 was most faithful to the source text, from the incipit the nature of the narrative structure (told wholly from Sookie's first-person perspective) is willfully forsaken: rather than an intimate subjective vision of an increasingly crazy world, the series makes the decision to focus on an ensemble cast, and many of the characters that are soon killed off or disappear from the novels take on a storyline of their own as the seasons go by.

However, to come back once again to the original Atlantic article, the author insisted not only on fidelity to the source text, but to its world: fantasy (along with science fiction) is unusual in that it creates a world adjacent to our own, and that world must be as believable as the characters or the plotlines if the fiction is to succeed. Ultimately, I will argue that True Blood seeks to increase the echo between text and TV series, by creating a constant distance not only from its source text but also from its characters and the events its recounts. After all, True Blood recounts a world much like our own, that just so happens to be populated by supernatural creatures - by creating various defamiliarizing elements (including invented episodes, but also comic or outrageous effects to distance the viewer from the characters' emotions), the show creators force us to pull back from the story and consider its implications. Game of Thrones, on the contrary, wants to pull the reader in, minimizing this "echo": when creating a world more typical of the fantasy genre, with religions, languages, and political hierarchies that are familiar to the characters but not the viewer, a distancing effect would be disastrous to the suspension of disbelief necessary to enter these new worlds. This is perhaps best reflected in the opening credits of the series, where the maps that open Martin's novel become three-dimensional and take shape before our eyes, literally bringing the viewer into this new world. (see plate 1) 


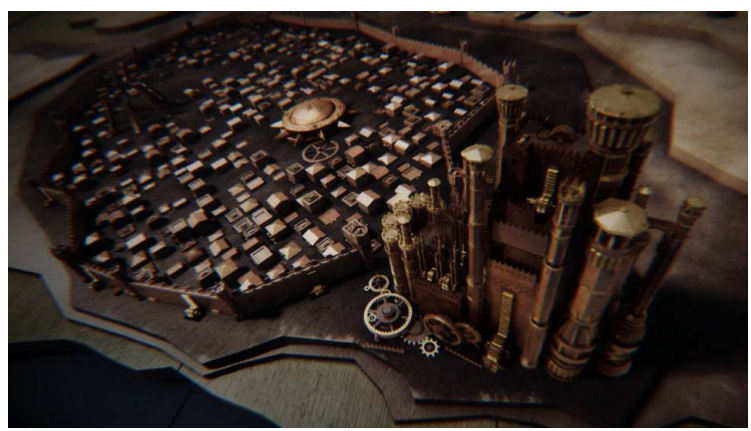

Plate 1: A world coming to life for the viewer

(Game of Thrones opening credits)

Though I refer to both of these series as fantasy, they in fact harken back to very different traditions and contexts, to which they must also refer in order to position themselves for the audience: one is not just faithful to a text, but to the literary tradition that inspired the authors. Making a series about vampires like True Blood implies taking into account representations of vampires from Bram Stoker onwards, as symbols of animal nature, sexuality, exoticism, inner darkness, etc. Making a series about vampires in the wake of Twilight mania implies positioning oneself in relation to the metaphor for abstinence and selfcontrol. It is no coincidence that our main character is a virgin that is soon corrupted by a vampire, and who thereafter spends most of her time naked. Nor is it surprising that the previous exoticism of the vampires takes on a decidedly Orientalist bent when the True Blood vampires become the symbol of otherness, of a minority that may or may not be dangerous to the "American way of life" attempting to fight for its rights, where the vampire authority figure (Eric Northman) makes his living by creating a theme bar that, we are told, is the Disneyland version of a vampire bar (1.4), complete with souvenir Tshirts ${ }^{9}$. Clearly, Harris chose this theme as a contradiction of a previous tradition, and Ball has taken that innovation and expanded on it. Its notes of comedy and camp could in fact be attributed to yet

9 In his now canonical work Orientalism that essentially began Postcolonial studies, Edward Saïd suggests that the European vision of "Orientals" (read: non-Westerners) makes them primarily representations of "Otherness", both in a negative sense, garnering all of the West's most pernicious qualities (licentiousness, violence, laziness, bestiality, etc.) as well as in a more positive sense, as exotic and mysterious. Thus, Saïd insists that Western culture has largely been built in response to this Oriental other. More importantly, Saïd suggests that this vision has not only shaped the West, but "the Orient" as well, which has come to conform to Western expectations. This conformity to well-known stereotypes is of course the basis of Fangtasia's success, though Eric Northman is portrayed as being selfaware, profiting from the implicit racism rather than seeking to curtail it. Edward Saïd, Orientalism, New York, Random House, 1979. 
another tradition, the supernatural sitcoms mentioned earlier, since the premise is essentially the same - here, too, supernatural creatures are attempting to assimilate into American society more or less successfully, and comedy is the result as often as tragedy.

Likewise, high fantasy like $A$ Game of Thrones is also a fairly recent literary genre: though it harkens back to Arthurian legends from Sir Thomas Malory's Le Morte d'Arthur on, it was J.R.R. Tolkien who created the genre of an imaginary medieval world as an allegory for the onslaught of industrialization in Jolly old England, i.e. The Shire. Martin seems to be explicitly referencing the master - it is no coincidence that he goes by "GRR" Martin, like "JRR" Tolkien, and though he admits his fascination for Tolkien's classic series The Lord of the Ring s $^{10}$, his saga chooses to counter Tolkien's nostalgia with issues like slavery, corruption, sexual violence, and oppression, making it an echo of our own imperfect society. At the same time, Tolkien spawned not only literary, but cultural progeny - from Dungeons and Dragons to World of Warcraft, adapting high fantasy implies taking into account gaming fans as well as literary fans. As such, once again, the opening credits are a stroke of genius: the maps are reminiscent of Tolkien's maps of Middle Earth (as well as the ever-broadening maps of Westeros with each new tome of A Song of Ice and Fire), and the camera movement from one area to another is very similar to the imagery and movement of role-playing video games. Thus both True Blood and Game of Thrones acknowledge the tradition implicit in their source texts, though once again both undermine these traditions.

In order to give a practical example of the use of echo in True Blood and Game of Thrones, it seems appropriate to take a closer look at the framework each series provides in their opening moments; as such I will examine the cold opens of each pilot, to see exactly how they navigate this idea of proximity and distance in their world-building. The cold opens are important because in neither of the series do they include major characters or storylines that will be followed up in the ensuing episodes (at least not directly); instead, they serve to introduce the viewer to this new world, and give a concrete example of their relation to source text and to the viewer's world.

The most striking thing about the opening of Game of Thrones is the silence, the solemnity with which it begins - clearly this is a series that is going to take its time setting the scene before advancing the action. The opening image of faces behind a gate initially show little difference from our own universe, and though we then see them dressed in medieval garb and on horseback, the defamiliarisation is minimal: they are not dressed gaudily, or in hose and doublet, or even

${ }^{10}$ Lev Grossman, "George R.R. Martin's Dance with Dragons: A Masterpiece Worthy of Tolkien", in Time, July $7^{\text {th }}, 2011$,

www.time.com/time/arts/article/o,8599,2081774,00.html, last consulted December 2014. 
stylishly, in leather catsuits à la Xena - these are dark, practical clothes, quite similar to our own when attempting to stay warm. Though this is clearly not our world, it is a recognizable one. (see plate 2)

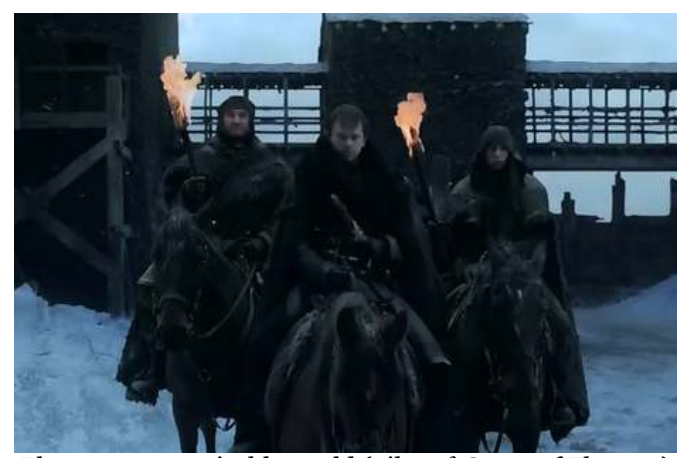

Plate 2: A recognizable world (pilot of Game of Thrones)

The fact that we cut from a gate opening to our characters going through a tunnel again emphasizes the idea that we are being drawn in to this world. It is only once we are "through the rabbit hole", if you will, that we get our first glimpse of a truly fantastic element, the Wall (an enormous 700-foot tall wall of ice meant to separate civilization from the Wildlings and the monsters who supposedly live on the other side). Even this sight is given to the viewer without fanfare or commentary, and is followed by yet another silence which allows the viewer to both absorb this new information and dread what this nowominous silence portends. We are not disappointed, of course: the violence and the fantastical elements then come fast and furious. It is once the Rangers first encounter the dead bodies that the series picks up the prologue largely as Martin wrote it, with one marked difference: the circle of body parts. In the novel, the scout assumes the bodies are dead because they are not moving, but can not be absolutely sure they are not simply sleeping, and this change made to the textual blueprint is made all the more violent in its contrast to the quiet opening. Beyond this, the circle seems to echo the astrolabe of the credit sequence: now that the series has drawn in its viewer, it emphasizes the unique nature not only of Westeros, but also the unique nature of the television series. The authors, while attempting to hew closely to the novels, also declare their independence.

True Blood also begins with an entirely invented sequence, immediately showing that these will not be the Sookie Stackhouse adventures; the consequences of vampires coming out of the shadows obviously outweigh a simple concern with the protagonist's love life. The opening teaser is voluntarily as close to our world as possible (in 
possibly sleazier), whether it be bored over-sexed college students looking for a cheap thrill, the reference to Hurricane Katrina, or the political comedy show Real Time with Bill Maher (HBO, 2003-) broadcasting on the TV at a Quick-E Mart (given its libertarian leanings, perhaps that is the least likely of the elements of the opening). We are lulled into complacency, only to have our expectations confounded when it is the hillbilly, rather than the goth who is a vampire. (see plate 3 )

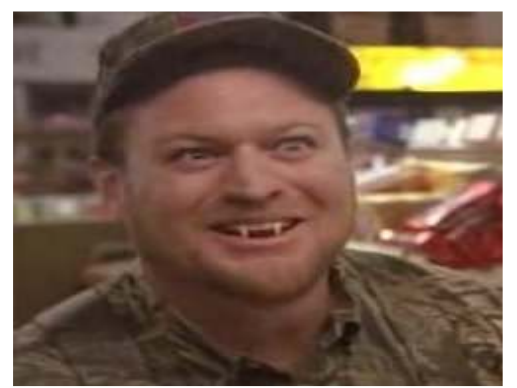

Plate 3: Confounding expectations

(pilot of True Blood)

Thus, rather than constantly attempting to pull us in to this world, Ball seems to be constantly pulling us back out: though we recognize this world, we should not be drawing assumptions. The vampire figure is not a vampire, the hillbilly character is not a hillbilly, and this is not reality, but TV.

Indeed, one of the ways that True Blood pulls us out of the story is quite simply by referencing its very nature as TV series on HBO. Real Time with Bill Maher is also an HBO show, and the pilot will go on to show Arlene, a fellow waitress at the bar where protagonist Sookie Stackhouse works, on the phone to her children, commenting: "If René thinks you're too young to watch a scary movie on HBO, I'm gonna side with him." (1.01) Later, one vampire will immobilize another by braining her with a plasma television - literally, we are being hit over the head with the idea that this is TV. (see plate 4) 


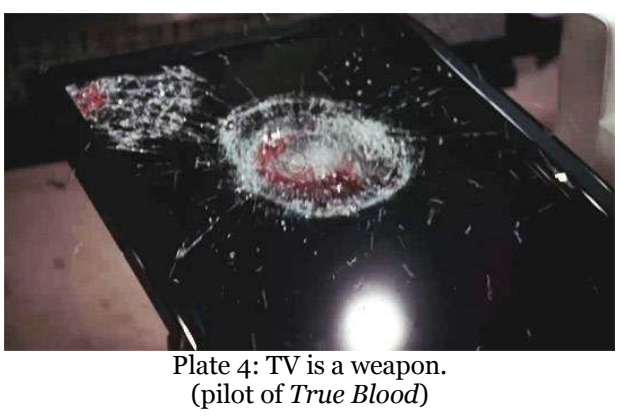

Though the pilot also shows Sookie's Gran reading a Charlene Harris book, thus explicitly acknowledging the source text, Sookie's beloved mentor then puts the novel away to listen to Sookie's story about the first sighting of Vampire Bill at Merlotte's bar - clearly, the book has been read, and then abandoned ${ }^{11}$.

Just as the viewer is constantly reminded not to get too sucked in to the story, that it is only TV, so Ball will continually frustrate viewers who tune in for the love stories that dominate the novels: Eric and Sookie might finally have their famous shower scene (4.8), a titillating set piece that kicks off their romantic relationship and remains a favorite of fans of the novel, but showrunner Alan Ball will not allow the viewer to simply bask the romanticism or the eroticism of it all; instead, this will be a surreal episode of a drug high, reminiscent of the relationship between Jason Stackhouse and psychopath Amy (1.9), whose drug-fueled relationship led to murder (of a vampire and Amy herself). (see plates 5 to8)

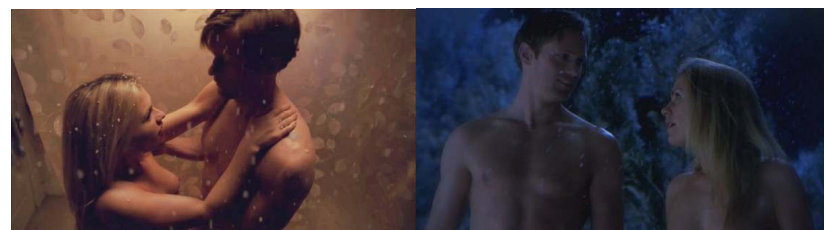

Plates 5 and 6: A fantasy sequence that hearkens back to season 1 (True Blood, 4.8)

${ }^{11}$ In fact, Gran herself will soon suffer the same fate as the novel, as she is soon the victim of a vampire-hating serial killer; she is dismissed from the plot of the series, but will be occasionally revived later in the show for the purposes of the narrative. 


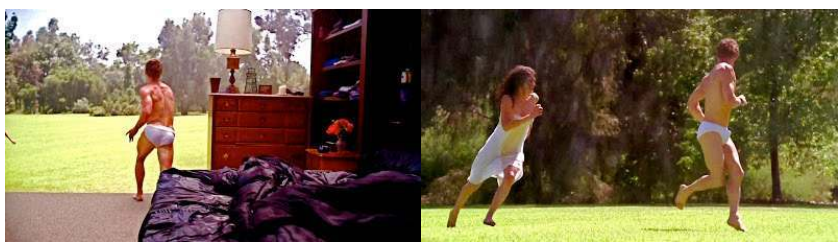

Plates 7 and 8: The apparently idyllic (but drug-fuelled) dream

$$
\text { (True Blood, 1.9) }
$$

In so doing, the viewer must take a step back - not just from the source text, but from the TV series itself, and acknowledge that the series is not simply a plotline (who will Sookie sleep with next?), but a series of metaphors or allegories about difference, religion, and sexuality in contemporary America. Though titillation remains a major part of the series, Ball never allows us to lapse into complacency, passively enjoying the eye candy: instead we are forced to acknowledge our voyeurism and the sentimental nature of our desire for the heroine to end up with our favorite sexy vampire, whichever character that may be. If we can take up the metaphor of the echo once again, we could say that by increasing the distance between novel and series, between story and suspension of disbelief, the resonance (political and artistic) increases.

Of course "it's not TV, it's HBO"! The premium cable channel has made itself not just a studio, but a brand, characterized as "quality television", with complex and often unlikeable protagonists, provocative topics, and lots of sex and violence. Both True Blood and Game of Thrones are noticeably more sexy and gory than their sources (as the body parts in the Game of Thrones cold open can attest), and the actors and producers are insistent that these are HBO shows - it could only happen on HBO, says Peter Dinklage ${ }^{12}$, while Kit Harington declares that despite the fantasy trappings, Game of Thrones is like any other HBO show ${ }^{13}$. Both True Blood and Game of Thrones have come under fire for their provocative sexuality, making TV critics regard the one as a guilty pleasure, while the other comes under fire for its use of "sexposition" - sex scenes going on in the background while exposition

\footnotetext{
12 The actor said as much during his Emmy acceptance speech: www.youtube.com/\#/watch?v=lu8pSihUJvM\&desktop_uri=\%2Fwatch\%3Fv\%3Dlu8pSihU

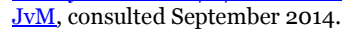

${ }^{13}$ Jace Lacob, "Kit Harington on 'Game of Thrones', Fame, and playing emo hero Jon Snow", The Daily Beast, April 9 $9^{\text {th }}, 2012$.

http://www.thedailybeast.com/articles/2012/04/o9/kit-harington-on-game-of-thronesfame-and-playing-emo-hero-jon-snow.html, consulted December 2014.
} 
is given, in an attempt to keep the viewer's interest (though perhaps not his whole attention) ${ }^{14}$.

I would like to conclude by discussing a comment made by George R.R. Martin in an interview about Game of Thrones ${ }^{15}$. He spoke of "The Butterfly Effect" in relation to adaptation, referring of course to the Ray Bradbury short story where the rich can go back in time and hunt dinosaurs - but one of them steps off the path and steps on a butterfly, and the world they come back to is unrecognizable. Martin suggests that for each change made to the original story, there is a domino effect for the rest of the story to come (he was speaking specifically of a character who is injured in a way that makes his further participation in the plot impossible). Going along with that, I would say that adapting these novels for the screen is changing the past, and therefore creating a new future - though we create perhaps parallel universes rather than obliterating the past. Though these two series take very different stances towards fidelity, whether it be to text, genre, medium, or channel, their end goals are essentially the same: to create an enjoyable experience that allows viewers to ponder the relationship between their world and ours. Given the audiences and the debates waged every Sunday night, I would argue that both these series are therefore successful adaptations.

\section{Bibliography}

Cartmell Deborah, Whelehan Imelda, Screen Adaptation: Impure Cinema, London, Palgrave Macmillan, 2010.

ElLIOTT Kamilla, Rethinking the Novel/Film Debate, Cambridge, Cambridge University Press, 2003.

Grossman Lev, “George R.R. Martin's Dance with Dragons: A Masterpiece Worthy of Tolkien", Time, July $7^{\text {th }}, 2011$, www.time.com/time/arts/article/o,8599,2081774,00.html, last consulted December 2014.

HARRIS Charlaine, Dead Until Dark, New York, Ace Books, 2001. --, Living Dead in Dallas, New York, Ace Books, 2002.

${ }^{14}$ See for example Mary McNamara, "HBO, you're busted”, Los Angeles Times, July $3^{\text {rd }}$, 2011; or James Poniewozik, "Breast Practices: Too many boobs in Game of Thrones?”, Time, July $7^{\text {th }}, 2011$.

${ }^{15}$ Adam Pasick, "George R.R. Martin on his favorite Game of Thrones actors, and the Butterfly Effect of TV Adaptations", Vulture, October $20^{\text {th }}, 2011$.

http://www.vulture.com/2011/10/george $\mathrm{rr}$ martin on his favori.html, last consulted December 2014. 
--, Club Dead, New York, Ace Books, 2003.

--, Dead to the World, New York, Ace Books, 2004.

--, Dead as a Doornail, New York, Ace Books, 2005.

--, Definitely Dead, New York, $\quad$ Ace Books, 2006.

--, All Together Dead, New York, Ace Books, 2007.

--, From Dead to Worse, New York, Ace Books, 2008.

--, Dead and Gone, New York, Ace Books, 2009.

--, Dead in the Family, New York, Ace Books, 2010.

--, Dead Reckoning, New York, Ace Books, 2011.

--, Deadlocked, New York, Ace Books, 2012.

--, Dead Ever After, New York, Ace Books, 2013.

Hutcheon Linda, A Theory of Adaptation, New York, Routledge, 2006.

LACOB Jace, "Kit Harington on 'Game of Thrones', Fame, and playing emo hero Jon Snow", The Daily Beast, April 9 ${ }^{\text {th }}$ 2012, http://www.thedailybeast.com/articles/2012/04/o9/kit-haringtonon-game-of-thrones-fame-and-playing-emo-hero-jon-snow.html, last consulted December 2014.

LEITCH Thomas, Film Adaptation and Its Discontents: From Gone with the Wind to The Passion of the Christ, Baltimore, John Hopkins University Press, 2007.

Martin George R. R., A Game of Thrones, New York, Bantam Books, 1996.

--, A Clash of Kings, New York, Bantam Books, 1999.

--, A Storm of Swords, New York, Bantam Books, 2000.

--, A Feast for Crows, New York, Bantam Books, 2005.

--, A Dance with Dragons, New York, Bantam Books, 2011.

McNAmara Mary, “HBO, you're busted”, Los Angeles Times, July $3^{\text {rd, }}$ 2011.

NAREMORE James, "Introduction", Film Adaptation, New Brunswick, NJ, Rutgers University Press, 2000, p. 11-12.

PASICK Adam, "George R.R. Martin on his favorite Game of Thrones actors, and the Butterfly Effect of TV Adaptations", Vulture, October $20^{\text {th }}, 2011$,

http://www.vulture.com/2011/10/george $\mathrm{rr}$ martin on his favori.h tml, last consulted December 2014.

PoniewozIK James, "Breast Practices: Too many boobs in Game of Thrones?”, Time, July $7^{\text {th }}, 2011$. 
Rosenberg Alyssa, "Fantasy on TV: How 'Game of Thrones' succeeds where 'True Blood' fails", The Atlantic, August 31, 2011, http://www.theatlantic.com/entertainment/archive/2011/08/fantasyon-tv-how-game-of-thrones- succeeds-where-true-blood-fails/244.365/, last consulted December $8^{\text {th }}, 2014$.

SAÏD Edward, Orientalism, New York, Random House, 1979.

STACK Tim, “True Blood': Alan Ball and Charlaine Harris discuss Sunday's shocking death of [SPOILER]", Entertainment Weekly, July $12^{\text {th }}, 2011$, www.insidetv.ew.com/2011/07/12/true-blood-alan-ballclaudine-death/, last consulted December 2014.

STAM Robert (ed.), Literature and Film: A Guide to the Theory and Practice of Film Adaptation, Malden, MA, Blackwell, 2005.

Thomas June, "How much gold is Game of Thrones worth?", Slate, March 29 ${ }^{\text {th }}, 2012$, http://www.slate.com/articles/arts/culturebox/2012/03/game of thr ones how hbo and showtime make money despite low ratings .html, last consulted December $8^{\text {th }} 2014$.

\section{The author}

Shannon Wells-Lassagne is an associate professor (maître de conférences) at the Université de Bretagne Sud in Lorient, France. She works primarily on the relationship between literature and film and television. She is the co-author (with Laurent Mellet) of Étudier l'adaptation filmique: cinéma anglais, cinéma américain (Presses Universitaires de Rennes, 2010), and the co-editor (with Ariane Hudelet) of Screening Text: Critical Perspectives on Film Adaptation (McFarland, 2013), De la page blanche aux salles obscures: l'adaptation filmique dans le monde anglophone (Presses Universitaires de Rennes, 2011), and (with Delphine Letort) of L'Adaptation cinématographique: premières pages, premiers plans (Mare et Martin, 2014). She has also edited special issues of Interfaces ("Expanding Adaptations", No. 34, with Ariane Hudelet) and GRAAT Online ("Television and Narratology: New Avenues in Storytelling", No. 15, with Georges-Claude Guilbert). Her work has appeared in The Journal of Adaptation in Film and Performance, Critical Studies in Television, Etudes britanniques contemporaines, Irish Studies Review, The Journal of the Short Story in English, Cinémaction, and Études irlandaises. 